\title{
ANALYSIS OF MARKETING MIX ON CUSTOMER SATISFACTION: EMPIRICAL STUDY OF PURCHASING DECISION OF EAST NUSA TENGGARA LOCAL PRODUCT
}

\author{
Sonya Lisabel Malelak ${ }^{1 *}$, Budi Setiawan ${ }^{2}$, Silvana Maulidah ${ }^{2}$ \\ ${ }^{1}$ Post Graduate Program, Faculty of Agriculture, Brawijaya University, Indonesia \\ ${ }^{2}$ Faculty of Agriculture, Brawijaya University, Indonesia \\ *corresponding author: sonyamalelak@gmail.com
}

\begin{abstract}
The purpose of this study is to analyze the effect of marketing mix on purchasing decisions of East Nusa Tenggara local products, to analyze the effect of marketing mix on consumer satisfaction of local products and to analyze the indirect effect of marketing mix on research satisfaction. The results showed that the variable price, place, promotion directly had a positive and significant effect on the purchasing decision variable. The product variable directly has a positive but insignificant effect. variable product, price, place, promotion directly have a positive and significant effect on customer satisfaction variables. The purchasing decision variable is not indirectly a mediation for the product variable and the consumer satisfaction variable. The purchase decision variable is not indirectly a mediation for the price variable and the consumer satisfaction variable. The purchase decision variable is not indirectly a mediation for the place variable and the consumer satisfaction variable. The purchasing decision variable is indirectly mediating for the promotion variable and the customer satisfaction variable.
\end{abstract}

Keywords: Marketing Mix, Purchasing Decision, Customer Satisfaction, SEM-PLS, East Nusa Tenggara Local Product

http://dx.doi.org/10.21776/ub.agrise.2021.021.4.4

Received 3 May 2021

Accepted 11 October 2021

Available online 31 October 2021

\section{INTRODUCTION}

Agro-industry is not a strange thing for Indonesia. In the future, the role of agro-industry is highly expected in reducing poverty and unemployment problems as well as driving rural industrialization (Hanani, 2003). In developing an agro-industry, one of the things needed is to see from the agro-industry marketing mix. The marketing mix is a device consisting of product, price, promotion and distribution, which will determine the level of marketing success and all of it is aimed at getting the desired response from the target market (Kotler and Keller, 2007). A good marketing mix will make consumers make purchasing decisions and feel satisfied / dissatisfied with the product. Satisfaction is the level of feeling a person feels after comparing the performance or results he feels compared to his expectations (Kotler, 2008). The level of satisfaction is very subjective where the measure of satisfaction from one customer to another customer will be different. This is caused by several factors such as age, occupation, income, education, gender, social position, economic level, culture, mental attitude and personality. So the level of satisfaction is a function of the difference between the perceived performance and expectations (Haris, 2015).

The beef cattle population in East Nusa Tenggara is quite large, which is evidenced by data from BPS regarding the beef cattle population in 2019 of $1,087,615$ heads. Beef cattle are usually used to be sent out of the Nusa area East Southeast and meet the demand for beef in East Nusa Tenggara. Given the perishable nature of beef, it is necessary to process the meat. Therefore, this is an opportunity for the agro-industry in East Nusa Tenggara to process beef into processed beef. Mrs. Soekiran's souvenir center is one of the agroindustries in Kupang City that processes beef into local and superior products. The importance of researchers conducting this research because se'i sapi is a unique souvenir from East Nusa Tenggara which is only in Kupang City that needs to be developed. As for previous studies, namely Agus Riyadi and Sarah Febriani Rangkuti, it shows that the influence of marketing mix and consumer 
satisfaction has a strong effect, Mohammed Abdelhady et al. al. show that product, promotion place has an effect on purchasing decisions, Retno et al. shows that the most influential marketing mix variable is price. Based on this introduction, this study focuses on the effect of the marketing mix on purchasing decisions and consumer satisfaction of local products in Kupang City.

\section{RESEARCH METHODOLOGY}

This research was conducted at the Center for Souvenirs of Ibu Soekiran. The research site was chosen purposely (Purposive) and based on objective considerations: it is the most famous selling place for local products and a favorite place for tourists who come to Kupang City. The study was conducted in March 2021. The determination of the sample in this study was carried out deliberately (purposive sampling). Samples taken are local product consumers. Sampling uses ten times the number of structural paths, namely 14 . So, the sample taken is 140 respondents. Methods of data collection are done by means of observation, interviews and distributing questionnaires. In this study, using the SEM War-PLS data analysis method.

Based on the framework of thought, the following hypothesis can be formulated:

H1: Marketing mix has a positive effect on purchasing decisions for East Nusa Tenggara local products.

H2: Marketing Mix has a positive effect on consumer satisfaction of East Nusa Tenggara local product.

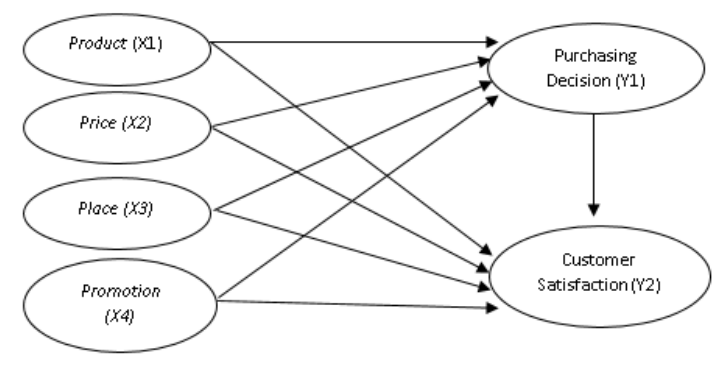

Figure 1. Research Model

\section{RESULTS AND DISCUSSION}

\section{Result}

\section{Characteristics of Respondents}

Table 1 shows the frequencies and percentages describing the sample in terms of gender, age, domicile, latest education and occupation.

\begin{tabular}{|l|l|l|l|}
\hline Demographic & Option & Amount & Persentage \\
\hline \multirow{5}{*}{ Aender } & Male & 67 & $47,9 \%$ \\
\cline { 2 - 4 } & Female & 73 & $52,1 \%$ \\
\cline { 2 - 4 } & Total & 140 & $100 \%$ \\
\hline & $17-25$ & 102 & $72,9 \%$ \\
\cline { 2 - 4 } & $26-34$ & 18 & $12,9 \%$ \\
\cline { 2 - 4 } & $35-43$ & 7 & $5 \%$ \\
\cline { 2 - 4 } & $44-50$ & 5 & $3,5 \%$ \\
\cline { 2 - 4 } & $>50$ & 8 & $5,7 \%$ \\
\cline { 2 - 4 } & Total & 140 & $100 \%$ \\
\hline \multirow{5}{*}{ Domicile } & Kupang City & 91 & $65 \%$ \\
\cline { 2 - 4 } & Outside Kupang City & 49 & $35 \%$ \\
\cline { 2 - 4 } & Total & 140 & $100 \%$ \\
\hline Occupation & Senior High School & 54 & $38,6 \%$ \\
\cline { 2 - 4 } & S1 & 82 & $58,6 \%$ \\
\cline { 2 - 4 } & S2 & 4 & $2,8 \%$ \\
\hline & Government Employees & 21 & $15 \%$ \\
\cline { 2 - 4 } & Company Employees & 27 & $19,3 \%$ \\
\cline { 2 - 4 } & Entrepreneur & 52 & $37,1 \%$ \\
\cline { 2 - 4 } & Student & 34 & $2,3 \%$ \\
\cline { 2 - 4 } & Teacher & 3 & $2,2 \%$ \\
\cline { 2 - 4 } & Other & 140 & $100 \%$ \\
\cline { 2 - 3 } & Total & & \\
\hline
\end{tabular}

Source: Primary Output Analysis (2021) 
1. Distribution of respondent characteristics based on gender, the highest number of respondents is female with a total of 73 people with a percentage of $52.1 \%$.

2. The distribution of respondent characteristics based on age, the largest number of respondents is at the age of 17-25 years with a total of 102 people with a percentage of $72.9 \%$.

3. Distribution of respondent characteristics based on domicile, the largest number of respondents is domicile in Kupang City with a total of 91 people with a percentage of $65 \%$.

4. The distribution of respondent characteristics based on the latest education, the largest number of respondents, namely $\mathrm{S} 1$ with a total of 82 people with a percentage of $58.6 \%$.
5. Distribution of characteristics of respondents based on occupation, the highest number of respondents is self-employed with a total of 52 people with a percentage of $37.1 \%$.

\section{Validity and Reliability Testing}

Reliability testing is seen from the value of Composite Reliability and Cronbach's Alpha. If the value of composite reliability $>0.70$ and Cronbach's Alpha value> 0.60 , it is considered to meet the criteria for reliability requirements. Validity testing is seen from the value of Average Variances Extracted (AVE) and Discriminant Validity, if the AVE value is $>0.50$ and the loading value of each indicator is greater than the cross loading value of other latent variables, it is considered to meet the validity requirements (Solimun, 2017).

Table 2 Validity and Reliability Testing

\begin{tabular}{|c|c|c|c|c|c|c|c|}
\hline \multirow{3}{*}{$\begin{array}{c}\text { Latent } \\
\text { Variable }\end{array}$} & \multirow{3}{*}{$\begin{array}{c}\text { Indicato } \\
\mathbf{r}\end{array}$} & \multicolumn{3}{|c|}{ Construct Validity Test } & \multirow{3}{*}{$\begin{array}{l}\text { Composit } \\
\text { e } \\
\text { Reliability }\end{array}$} & \multirow[b]{3}{*}{$\begin{array}{c}\text { Cronbach' } \\
\text { s Alpha }\end{array}$} & \multirow[b]{3}{*}{ AVE } \\
\hline & & \multicolumn{3}{|c|}{ (Signifikansi Weight < 0,05 = Valid) } & & & \\
\hline & & $\begin{array}{c}\text { Loading } \\
\text { Factor }\end{array}$ & P-Value & $\begin{array}{c}\text { Conclusi } \\
\text { on }\end{array}$ & & & \\
\hline \multirow{2}{*}{$\begin{array}{l}\text { Product } \\
\text { (X1) }\end{array}$} & $\mathrm{X} 1.1$ & 0.997 & $<0.001$ & Valid & \multirow[t]{2}{*}{0.997} & \multirow[t]{2}{*}{0.995} & \multirow[t]{2}{*}{0.995} \\
\hline & $\mathrm{X} 1.2$ & 0.997 & $<0.001$ & Valid & & & \\
\hline \multirow[t]{2}{*}{ Price $(\mathrm{X} 2)$} & $\mathrm{X} 2.1$ & 0.979 & $<0.001$ & Valid & \multirow[t]{2}{*}{0.979} & \multirow[t]{2}{*}{0.958} & \multirow[t]{2}{*}{0.959} \\
\hline & $\mathrm{X} 2.2$ & 0.979 & $<0.001$ & Valid & & & \\
\hline \multirow[t]{2}{*}{ Place (X3) } & $\mathrm{X} 3.1$ & 0.974 & $<0.001$ & Valid & \multirow[t]{2}{*}{0.973} & \multirow[t]{2}{*}{0.945} & \multirow[t]{2}{*}{0.948} \\
\hline & $\mathrm{X} 3.2$ & 0.974 & $<0.001$ & Valid & & & \\
\hline \multirow{2}{*}{$\begin{array}{l}\text { Promotion } \\
\text { (X4) }\end{array}$} & $\mathrm{X} 4.1$ & 0.988 & $<0.001$ & Valid & \multirow[t]{2}{*}{0.987} & \multirow[t]{2}{*}{0.975} & \multirow[t]{2}{*}{0.975} \\
\hline & $\mathrm{X} 4.2$ & 0.988 & $<0.001$ & Valid & & & \\
\hline \multirow{2}{*}{$\begin{array}{l}\text { Purchasin } \\
\text { g Decision } \\
\text { (Y1) }\end{array}$} & Y1.1 & 0.986 & $<0.001$ & Valid & \multirow[t]{2}{*}{0.986} & \multirow[t]{2}{*}{0.971} & \multirow[t]{2}{*}{0.972} \\
\hline & Y1.2 & 0.986 & $<0.001$ & Valid & & & \\
\hline \multirow{2}{*}{$\begin{array}{l}\text { Customer } \\
\text { Satisfactio } \\
\text { n (Y2) }\end{array}$} & Y2.1 & 0.988 & $<0.001$ & Valid & \multirow[t]{2}{*}{0.988} & \multirow[t]{2}{*}{0.976} & \multirow[t]{2}{*}{0.977} \\
\hline & Y2.2 & 0.988 & $<0.001$ & Valid & & & \\
\hline
\end{tabular}

Source: Primary Output Analysis (2021)

Based on the data in table 2, the Composite Reliability value on the latent variables has met the criteria, namely the value is $>0.70$, the Cronbach's Alpha value on the latent variables has met the criteria, namely the value is> 0.60 , and the AVE value on the variables - the latent variable has met the criteria, namely the value $>0.50$. Therefore, it can be said that the measurement model reflects the validity and reliability of the construct well so that it can be trusted to present the research variables.

\section{Model Fit and Quality Indices}

Goodness of fit is an index and measure of the goodness of the relationship between latent variables (inner model) and its assumptions. 
Table 3 Model Fit and Quality Indices

\begin{tabular}{|c|c|c|c|c|}
\hline No. & Model fit and quality indices & Fit Criteria & Analysis Result & Explanation \\
\hline 1 & Average path coefficient (APC) & $\mathrm{p}<0.05$ & $0.272(\mathrm{p}<0.001)$ & Good \\
\hline 2 & Average R-squared (ARS) & $\mathrm{p}<0.05$ & $0.912(\mathrm{p}<0.001)$ & Good \\
\hline 3 & $\begin{array}{c}\text { Average adjusted R-squared } \\
\text { (AARS) }\end{array}$ & $\mathrm{p}<0.05$ & $0.909(\mathrm{p}<0.001)$ & Good \\
\hline 4 & Average block VIF (AVIF) & $\begin{array}{c}\text { Acceptable if }<=5 \text {, ideally } \\
<=3.3\end{array}$ & 3.618 & Good \\
\hline 5 & $\begin{array}{l}\text { Average full collinearity VIF } \\
\text { (AFVIF) }\end{array}$ & $\begin{array}{c}\text { Acceptable if }<=5 \text {, ideally } \\
<=3.3\end{array}$ & 3.014 & Ideally \\
\hline 6 & Tenenhaus GoF (GoF) & $\begin{array}{c}\text { Small }>=0.1, \text { medium }>= \\
0.25, \text { large }>=0.36\end{array}$ & 0.941 & Large \\
\hline 7 & Sympson's paradox ratio (SPR) & $\begin{array}{c}\text { Acceptable if }>=0.7, \\
\text { ideally }=1\end{array}$ & 1.000 & Ideally \\
\hline 8 & $\begin{array}{l}\text { R-squared contribution ratio } \\
\text { (RSCR) }\end{array}$ & $\begin{array}{c}\text { Acceptable if }>=0.9, \\
\text { ideally }=1\end{array}$ & 1.000 & Ideally \\
\hline 9 & $\begin{array}{c}\text { Statiscal suppression ratio } \\
\text { (SSR) }\end{array}$ & Acceptable if $>=0.7$ & 1.000 & Ideally \\
\hline 10 & $\begin{array}{l}\text { Nonlinear bivariate causality } \\
\text { direction ratio (NLBCDR) }\end{array}$ & Acceptable if $>=0.7$ & 1.000 & Ideally \\
\hline
\end{tabular}

Source: Primary Output Analysis (2021)

Based on the data from table 3, it can be said that the model has met the criteria so that it can be said that this model has a good Goodness of Fit.

\section{Hypothesis test}

Table 4 Hypothesis Testing in the Inner Model: Direct Effects

\begin{tabular}{|c|c|c|c|c|c|}
\hline No. & $\begin{array}{c}\text { Explanatory } \\
\text { Variable }\end{array}$ & Response Variable & $\begin{array}{c}\text { Path } \\
\text { Coefficient }\end{array}$ & p-value & Explanation \\
\hline \multirow[t]{2}{*}{1.} & \multirow[t]{2}{*}{ Product $(\mathrm{X} 1)$} & Purchasing Decision (Y1) & 0.078 & 0.175 & Non Significant \\
\hline & & Customer Satisfaction (Y2) & 0.345 & $<0.001$ & Significant \\
\hline \multirow[t]{2}{*}{2.} & \multirow[t]{2}{*}{ Price (X2) } & Purchasing Decision (Y1) & 0.138 & 0.048 & Significant \\
\hline & & Customer Satisfaction (Y2) & 0.223 & 0.003 & Significant \\
\hline \multirow[t]{2}{*}{3.} & \multirow[t]{2}{*}{ Place (X3) } & Purchasing Decision (Y1) & 0.204 & 0.006 & Significant \\
\hline & & Customer Satisfaction (Y2) & 0.274 & $<0.001$ & Significant \\
\hline \multirow[t]{2}{*}{4.} & \multirow[t]{2}{*}{ Promotion $(\mathrm{X} 4)$} & Purchasing Decision (Y1) & 0.638 & $<0.001$ & Significant \\
\hline & & Customer Satisfaction (Y2) & 0.186 & 0.012 & Significant \\
\hline 5. & $\begin{array}{l}\text { Purchasing } \\
\text { Decision (Y1) }\end{array}$ & Customer Satisfaction (Y2) & 0.303 & $<0.001$ & Significant \\
\hline
\end{tabular}

\section{Significant at the $5 \%$ level}

Source: Primary Output Analysis (2021)

Table 4 shows that the effect of the marketing mix: price, place, and promotion has a positive and significant effect on purchasing decisions and customer satisfaction, while the product variable has a positive and significant effect on customer satisfaction, but not significant on purchasing decisions. 
Table 5 Hypothesis Testing in the Inner Model: Indirect Effects

\begin{tabular}{|c|c|c|c|c|c|}
\hline No. & Effects Testing & Mediation & Coefficient & $p$-value & Explanation \\
\hline 1. & $\mathrm{X} 1 \rightarrow \mathrm{Y} 2$ & $\mathrm{Y} 1$ & 0.024 & 0.346 & Non Mediation \\
\hline 2. & $\mathrm{X} 2 \rightarrow \mathrm{Y} 2$ & $\mathrm{Y} 1$ & 0.042 & 0.241 & Non Mediation \\
\hline 3. & $\mathrm{X} 3 \rightarrow \mathrm{Y} 2$ & $\mathrm{Y} 1$ & 0.093 & 0.148 & Non Mediation \\
\hline 4. & $\mathrm{X} 4 \rightarrow \mathrm{Y} 2$ & $\mathrm{Y} 1$ & 0.194 & $<0.001$ & Mediation \\
\hline
\end{tabular}

Significant at the $5 \%$ level

Source:Primary Output Analysis (2021)

Based on the data in table 5, the purchase satisfaction variable (Y1) serves as a mediation for the promotion variable and the customer satisfaction variable, while for the other variables the purchasing decision variable is not a mediation.

\section{Discussion}

East Nusa Tenggara local product is a food product made from the basic ingredients of beef with spices, cooked by smoking until cooked. In the cooking process, use selected wood for the burning and smoked process. Usually this product is named "Daging se'i sapi".

Based on the data in table 4, the product has a positive and insignificant effect on purchasing decisions. This result contradicts the research conducted by Dewi et al. (2018) who found that product, promotion, employees, and satisfaction had a positive and significant effect on customer satisfaction at PT. TIKI Padang Branch. There is research that supports these results, namely the product has no effect on purchasing decisions (Farahnur, 2020). The product variable does have an effect on purchasing decisions but the effect is very small. This is due to the Covid-19 pandemic, many tourists have not traveled to Kupang City and people have lost their jobs so that the purchasing power of consumers is reduced. Variable Product variables have a positive and significant effect on customer satisfaction. Although the purchase of local products is reduced, consumers of local products are satisfied because of the unique and delicious taste of local products so that it is in accordance with consumer expectations / expectations and the service from the Souvenir Center provided to consumers when buying local products is done well.

The results showed that the price variable had a positive and significant effect on purchasing decisions. The components of the marketing mix that most influence purchasing decisions are price and promotion (Parmana et al. 2019). Brand image and price / price have a simultaneous and positive effect on purchasing decisions (Albari, 2020). The price of local products is quite affordable, namely
IDR 115,000 / 500 gr so that consumers are interested in buying these products. The price variable has a positive and significant effect on the consumer satisfaction variable. Prices of local products are affordable in all circles and prices are in accordance with the perceived quality of beef se'i beef so that consumers feel satisfied because it is in accordance with what consumers expect.

The components of the marketing mix have an influence on customer satisfaction where the components of the product, price, location, and promotion together have a positive effect on customer satisfaction. The results showed that the place variable had a positive and significant effect on purchasing decisions. The results of this study are in accordance with the research of Widyastuti et al. (2020) which shows that place has an effect on purchasing decisions. Mrs. Soekiran's Souvenir Center is located on the side of the main road in the city and is surrounded by offices, housing and shops so that it is easily accessible by the public and tourists so that it is not difficult to find the place. The place variable has a positive and significant effect on customer satisfaction. In addition to a place that is easily accessible to consumers, East Nusa Tenggara local product stocks are also always available at Mrs. Soekiran's Souvenir Center so that consumers don't need to be afraid of running out of stock of these products and this is what makes consumers feel satisfied.

The results show that the promotion variable has a positive and significant effect on purchasing decisions. This result is in contrast to the research of Sunardi (2016) which shows that place and promotion do not significantly influence purchasing decisions. The marketing mix component has an influence on consumer satisfaction where the product components, price, 
location, and promotion together have a positive effect on customer satisfaction (Putu et al. 2016). Promotion has a positive effect on purchasing decisions (Darmasaputra, 2015). Ibu Soekiran's Souvenir Center carries out promotions using advertising, namely through social media such as Instagram, Facebook and others so that consumers can find out information about local products. The promotion variable has a positive and significant effect on customer satisfaction. In addition to advertising, Mrs. Soekiran's Souvenir Center also sells local products directly and online, making it easier for consumers to buy these products. Purchasing decision variables have a positive and significant effect on consumer satisfaction. Consumers decide to buy local products and these products are in accordance with consumer expectations, it will cause a sense of consumer satisfaction.

The results show that indirectly the purchasing decision variable is not a mediation for the product variable and the consumer satisfaction variable. Because without making a purchase decision, consumers already feel satisfaction, taste good products, attractive product packaging and use vacuum packaging so that the product is not easily damaged. The purchase decision variable is not a mediation for the price variable and the consumer satisfaction variable. Because local products are only one type of product, the price is affordable and there are no competitors, so without going through a purchase decision, consumers are satisfied with the product price. The purchase decision variable is not a mediation for the place variable and the customer satisfaction variable. Indirectly, without going through a purchase decision, consumers are satisfied with Mrs. Soekiran's Souvenir Center because the place is easily accessible to consumers and the products are always available in that place. The purchasing decision variable is a mediation for the promotion variable and the customer satisfaction variable. By looking at one form of promotion such as consumer advertising to make plans to make decisions purchase of local products. After buying and using these products, consumers will feel satisfied with the product because of the distinctive taste of the product and the attractive product packaging. Research by Darwin et al. shows that the customer satisfaction variable is a mediating variable between the relationship between service quality and consumer trust on customer loyalty. In the research of Rego Devila et al. shows that the marketing mix has a negative and significant effect on loyalty through customer satisfaction.

\section{CONCLUSION}

Based on the research results that have been described, it can be concluded as follows:

1) Marketing mix: the variable price, place, promotion directly has a positive and significant effect on the purchasing decision variable. The product variable directly has a positive but insignificant effect.

2) Marketing mix: product, price, place, promotion variables directly have a positive and significant effect on consumer satisfaction variables.

3) The purchasing decision variable is indirectly not a mediation for the product variable and the consumer satisfaction variable. The purchase decision variable is not indirectly a mediation for the price variable and the consumer satisfaction variable. The purchase decision variable is not indirectly a mediation for the place variable and the consumer satisfaction variable. The purchasing decision variable is indirectly mediating for the promotion variable and the customer satisfaction variable.

\section{REFERENCES}

Abdelhady, Mohamed, Hanaa Fayed, Nancy Fawzy. 2019. The Influence of Airlines Marketing Mix Elements on Passengers Purchasing Decision Making: The Case of FSCs and LCCs. International Journal of Hospitality $\&$ Tourism Systems.

Albari. 2020. The Influence of Product Price on Consumers Purchasing Decisions. Review Integrative Business and Economics Reasearch 7(328-336).

Astuti, Retno. 2015. Marketing Strategy Based on Marketing Mix Influence on Purchasing Decisions of Malang Apples Consumers at Giant Olympic Garden Mall (MOG), Malang City, East Java Province, Indonesia. Agriculture and Agricultural Science Procedia.

Central Bureau of Statistics [BPS]. Nusa province East Tenggara in Figures 2020. Central Bureau of Statistics of East Nusa Tenggara Province.

Darmasaputra, Randi. 2015. The Effect of Marketing Mix Towards Customer Purchase Decision Process. e- Proceeding of Management 2(1578-1582). 
Devila, Rego. 2017. Marketing Mix: Effects of Service Quality and Consumer Behaviour on Loyalty the Mediating Role of Customer Satisfaction.Journal of Research in Business and Management.Vol.4(23473002). [Online] tersedia: https://osf.io/svckm/download/?format=pd $\mathrm{f}$

Farahnur, Viona, Nani Ariani. 2020. Analysis of Marketing Mix on Purchase Decision of The Body Shop Product in Pejaten Village Mall Outlet. International Humanities and Applies Sciences Journal 3(1-11).

Hanani, N. 2003. Agricultural Development Strategy. Jogja Mandiri Library Printing. Bantul, Yogyakarta.

Hermawan, Haris. 2015. Analysis of the Mix Effect Marketing Decisions on Customer Satisfaction and Loyalty in Purchasing Cheerful Bread in Jember. Indonesian Journal of Management and Business.

Jamiyasa, I Made, I Made Pulawan, Media

Martadiani, I Made Suniastha Amerta. 2017. The MarketingMix Affect on the Consumer Buying Decision (Case Study of Sausage Products at PT. Aroma Denpasar). International Journal of Social Sciences and Humanities.

Kotler, Philip and Keller. 2007. Management Marketing, Volume I, Twelfth Edition. PT. Index, Jakarta

Kotler, Philip; Armstrong, Garry. 2008. Principles Principles of Marketing, Volume 1. Jakarta: Erlangga

Lie, Darwin, Acai Sudirman, Efendi, Marisi
Butarbutar. 2019.Analysis of Mediation Effect of Consumer Satisfaction on The Effect of Service Quality, Price and Consumer Trust on Consumer Loyalty. International Journal of Scientific \& Technology Reasearch.

Marlina, Dewi. 2018. Effect of Marketing Mix on Customer Satisfaction and Loyalty PT. TIKI Padang Branch.Advances in Economics, Business and Management Research. Vol. 64. [Online] tersedia: https://www.atlantispress.com/proceedings/piceeba218/125907939

Parmana, Idqan Fahmi, Dodik Ridho. 2019. The Influence of Marketing Mix Factors in PurchasingDecision for Wooden Furniture Case of Furnimart Bogor. Indonesian Journal of Business and Entrepeneurship.

Setiawan, Putu, Ahmad Fudholi, Satibi. 2016.

The Effect of Marketing Mix on Product Customer Satisfaction and Loyalty. Journal of Pharmaceutical Management and Services.

Solimun. 2017. Multivariate Statistical Methods Structural Equation Modeling (SEM) WarPLS Approach. Malang: UB Press

Sunardi. 2016. Analysis The Effect of Marketing Mix in Purchasing Decision of Growing Up Milk (GUM) On Three Socio-Economic Classes In Malang.. Agricultural SocioEconomics Journal 2(87-96)

Widyastuti, Ani Nor, Pujiharto, Naelati Tubastuvi, Suryo Budi Santoso. 2020. The Effect of Marketing Mix on Purchase Decision. Journal of Business Management. 
This page is intentionally left blank 